\title{
Presentation of Honorary Fellowships to Norma Cohen, Robin de Wilde and Gábor Hanák
}

\author{
[Institute and Faculty of Actuaries, London, 23 June 2016]
}

The President (Ms F. J. Morrison, F.I.A.): Norma Cohen is a well-respected journalist and commentator in demographics, with a recent career more focussed on research.

Having worked for the Financial Times for over 25 years, Norma has covered many areas, including capital markets, investment, economics and demography.

Some of the Institute and Faculty of Actuaries' (IFoA) early contact with Norma was through her role as demography correspondent for the Financial Times. This included an interview she conducted with Jane Curtis, then President of the IFoA, on a proposal from the UK Government on changes to pension schemes. She has also recently provided insight to IFoA's Council on the profession's Public Affairs and Promotion strategic objective.

Norma recently completed an MSc (research) in Economic History at London School of Economics, with a dissertation topic: "How did the actuarial profession's understanding of human longevity change over the course of the 19th century?” A regular user of the IFoA's library service, she is currently studying for a $\mathrm{PhD}$ at Queen Mary University, London, using a previously unopened archive on the sources of capital used to finance Britain during World War I. Her experience as a journalist and in-depth understanding of issues as a researcher, present a powerful combination to the actuarial profession.

Ms N. Cohen, H.F.I.A.: Ladies and gentlemen, thank you very much for voting for me to become an Honorary Fellow of the IFoA.

I am honoured to be voted into membership of a profession whose intellectual roots are based in the renaissance. Probability science, upon which the actuarial profession is founded, is a form of scientific enquiry that still has much to offer for the times we live in now.

The President: Robin de Wilde QC was called to the Bar in 1971 and made Queen's Counsel in 1993. He is a leading QC in the field of professional negligence, particularly personal injury and clinical negligence, including cerebral palsy and product liability.

Robin is Chairman of the Ogden Working Party, a position he has held since 2002, and is responsible in that capacity for the 5th, 6th and 7th editions of the Ogden Tables, in cooperation with actuaries from the Government Actuary's Department.

Robin also works with the actuarial profession in his professional practice and is committed to the importance of actuarial evidence in complex personal injury cases. He is a strong advocate of cooperation between actuaries and the legal profession, shaping the practice of the courts in this field. 
Mr R. de Wilde, H.F.I.A.: I am honoured and delighted to be made an Honorary Fellow of this eminent and distinguished body.

One problem is that lawyers are perennially frightened by figures, whereas the members of this company actually understand figures! It is said that the only figures that lawyers understand is when a "pound sign" is attached to them.

In my world, which is one where personal injury damages are calculated, mostly based on "Expectation of Life Tables", those figures can be very important for assessing the final damages. We rely on the "Expectation of Life Tables" produced by the Government Actuary's Department.

However, there are things that I have begun to appreciate that we do not understand, such as the fact that around Glasgow, there seems to be a particular "miasma" floating around and above the River Clyde which causes all the normal figures to be distorted. It is described as a "miasma" because there is no other easy explanation which rationalises the distortion of expectation of life figures in the Glasgow area.

Another problem which arises is that identical twins, with exactly the same genetic make up, hardly ever seem to live for the same periods. Denmark is the country which has been following "identical twins" since at least the 1850 s and is the only country which has been doing this for such a long period. However, even Denmark's figures cannot explain why such twins should not have the same longevity, unless it is what happens to such twins separately since birth, that is the experience of actually living a full life, which may be the determining feature.

I look forward to meeting members of this distinguished and learned body, who can explain to me, in simple terms, why these discrepancies take place.

The President: Gábor Hanák is former Chairman of the Groupe Consultatif Actuariel Européen (now Actuarial Association of Europe (AAE)) and a past president of the Hungarian Actuarial Society (HAS), of which he was a founding member.

Gábor has been the delegate of the HAS to the International Actuarial Association (IAA) and also a member of the Actuarial Standards Committee of the IAA.

Under his Chairmanship, the Groupe Consultatif developed a new strategy that is still in place today. He also encouraged the introduction of a liaison system whereby each Officer of the AAE has been responsible for liaising with member associations in Europe. He is now the Chairman of the AAE's Standards Project Team, which is responsible for developing European Standards of Actuarial Practice. During his time as Chairman of the Groupe Consultatif, he helped a number of actuarial associations by providing advice and presentations on both technical and professional subjects. He has been a key contributor to the development of the actuarial profession both in his home country of Hungary and around Europe.

Gábor's career in the insurance sector spans over 25 years. He was originally a mathematician until the early 1990s, when new and competing insurers emerged in the market place in Hungary, and he gravitated towards actuarial work. In 1999, he launched his own actuarial consultancy and provided actuarial advisory services in Hungary and in the Central Eastern European region until joining KPMG in 2008, where he is now Actuarial Director. 
Mr G. Hanák, H.F.I.A.: Ladies and gentlemen, it is a real honour for me to be awarded by this prestigious fellowship in recognition of my efforts in promoting the actuarial profession in Europe over the past few decades.

Especially joyful is that I become an Honorary Fellow of the IFoA as this association helped the revival of the profession in Hungary, and in many other countries in Eastern Europe. In the early 1990s, at that time as two separate bodies but by a joint effort, the Institute of Actuaries and the Faculty of Actuaries delivered many educational activities in my country and in others in the region.

I would like to take this opportunity to thank especially Chris Daykin, who is sitting in this room, for his great efforts in putting together the programmes of shorter training events and longer diploma courses that served starting an actuarial career for many young professionals in our region. I should also mention some other UK actuaries who helped us in our toddler age: beyond Chris, Neil Parrack and Leslie Tutt gave the very first presentations on actuarial science and practice in Hungary. That initial training very soon led to the founding, well actually reviving, of the profession in Hungary and 36 individuals founded the HAS. Today we have over 200 members and 80 fully qualified actuaries.

John McCutcheon also delivered a memorable 1 week training at the end of which he presented, on behalf of the Faculty of Actuaries, a gavel, very similar to the one your President is using now at this General Meeting. My home association still uses it at our General Meetings.

I would not dare to think that I am copying what Chris has been doing in being an international envoy of the actuarial profession, yet, in some respects I am following him, and I am proud of it. I took over the chairmanship of the Groupe Consultatif Actuariel Européen (today, the AAE) after Chris completed his term. I followed him in chairing the Standard Project Team, the AAE's body for developing European Standards of Actuarial Practice.

I believe I may have added something to the development of the actuarial profession in Europe. But, being an actuary, a retrospective view is as important as the prospective one. Thus, what is important is what we can do for the profession in the future - as challenges, like the role of the actuary in risk management and in future pensions, will never cease to exist. I hope I can still contribute to the profession's further development. 